\title{
Daily concentrations of air pollution and plasma fibrinogen in London
}

\author{
J Pekkanen, E J Brunner, H R Anderson, P Tiittanen, R W Atkinson
}

Unit of Environmental Epidemiology, National Public Health Institute, PO Box 95, FIN-70701 Kuopio, Finland

J Pekkanen

P Tiittanen

International Centre for Health and Society, Department of

Epidemiology and Public Health, University College

London Medical

School, London

WC1E 6BT, UK

E J Brunner

Department of Public Health Sciences, St George's Hospital

Medical School, Cranmer Terrace, London, SW17 0RE, UK

H R Anderson

$\mathrm{R}$ W Atkinson

Correspondence to: Dr Juha Pekkanen

Juha.Pekkanen@ktl.fi

Accepted 25 July 2000

\begin{abstract}
Objectives-The reason for the association between air pollution and risk of cardiovascular diseases is unknown. The hypothesis was examined that daily concentrations of air pollution are associated with daily concentrations of fibrinogen, a risk factor for cardiovascular disease.

Methods-Data on concentrations of plasma fibrinogen for $\mathbf{4 9 8 2}$ male and 2223 female office workers, collected in a cross sectional survey in London between September 1991 and May 1993, were combined with data on concentrations of air pollution during the day of blood sampling and during the 3 preceding days.

Results-After adjustment for weather and other confounding factors, an increase in the 24 hour mean $\mathrm{NO}_{2}$ during the previous day from the 10th to the 90th percentile $\left(61.7 \mu \mathrm{g} / \mathrm{m}^{3}\right)$ was associated with a $1.5 \%$ (95\% confidence interval $(95 \% \mathrm{CI})$ $0.4 \%$ to $2.5 \%$ ) higher fibrinogen concentration. The respective increase for $\mathbf{C O}$ $\left(1.6 \mathrm{mg} / \mathrm{m}^{3}\right)$ was $1.5 \%(95 \% \mathrm{CI} 0.5 \%, 2.5 \%)$. These associations tended to be stronger in the warm season (April to September). Significant associations were found for black smoke and particulate matter of diameter $10 \mu \mathrm{m}\left(\mathbf{P M}_{10}\right)$ only in the warm season. No association with fibrinogen was found for $\mathrm{SO}_{2}$ or ozone.

Conclusions-The short term association between air pollution, possibly from traffic, and risk of cardiovascular events may be at least partly mediated through increased concentrations of plasma fibrinogen, possibly due to an inflammatory reaction caused by air pollution.

(Occup Environ Med 2000;57:818-822)
\end{abstract}

Keywords: air pollution; fibrinogen; haemostatic factors

Associations between air pollution and daily cardiovascular mortality and morbidity have been reported from several cities, ${ }^{1-9}$ including London. ${ }^{10}{ }^{11}$ Two cohort studies have also reported associations of particulate air pollution with long term risk of cardiovascular death. ${ }^{12}{ }^{13}$ The reasons for these associations are, however, unknown. It has been suggested that air pollutants, especially particulate matter, may induce inflammation, which would increase the concentrations of acute phase reactants, including fibrinogen. ${ }^{14}$ Fibrinogen is an important risk factor for cardiovascular diseases, especially ischaemic heart disease, ${ }^{15}$ but also stroke and peripheral arterial disease. ${ }^{16}$ In support of this inflammation hypothesis, it was recently reported that plasma viscosity increased during an air pollution episode in Germany. ${ }^{17}$

We therefore examined the association between daily concentrations of air pollution and concentrations of plasma fibrinogen measured among 4982 male and 2223 female office workers in Whitehall, London between September 1991 and May 1993.

\section{Methods}

The demographic characteristics, health, and risk factors of the 10308 subjects $(6895$ men and 3413 women) in the Whitehall II study at baseline are published elsewhere. ${ }^{18}$ Subjects were recruited in 1985-8 by inviting all employees aged 35-55 from 20 London based civil service departments. The response rate was $73 \%$, but detailed investigation in one department showed that $4 \%$ of those on the list of employees had moved before recruitment, and so the true response rate was somewhat higher. The haemostatic data analysed here were measured at the second screening examination (1991-3) when 5616 men and 2488 women aged 39-63 years participated.

Venepuncture of the left antecubital vein was performed with tourniquet and blood was collected into Sarstedt citrate monovettes. After centrifugation samples were immediately frozen at $-80{ }^{\circ} \mathrm{C}$ and stored until assay. Fibrinogen was measured by an automated modification of the Clauss method. ${ }^{19}$ Technical error was estimated by assaying blinded duplicate samples for $5 \%$ of subjects. The coefficient of variation was $7.7 \%$.

The air pollution data were obtained from AEA Technology, NETCEN, Culham, Abingdon, Oxfordshire. We used 24 hour averages of $\mathrm{NO}_{2}$, particulate matter of diameter $10 \mu \mathrm{m}$ $\left(\mathrm{PM}_{10}\right)$, and $\mathrm{CO}$ and maximum 8 hour means of $\mathrm{O}_{3}$, all measured in central London. Black smoke and $\mathrm{SO}_{2}$ are 24 hour imputed averages for London from measurements from five sites: London City, Croydon in South London, Enfield in North London, Acton in West London, and Ilford in East London. Daily maximum and minimum temperature and 0600 and 1500 relative humidity measures at Holburn, central London, were obtained from the Meteorological Office.

In the analyses, fibrinogen was modelled in two ways. Firstly, in the linear regression models, fibrinogen was regressed on the air pollutants. Logarithmic transformation was indicated because of the log normal distribution of fibrinogen. We also tried a linear first order autoregressive model, but there was no evidence of autocorrelation. Secondly, in the 
Table 1 Distributions of plasma fibrinogen and air pollutants

\begin{tabular}{|c|c|c|c|c|c|c|}
\hline & $n$ & Median & $10 \%$ & $90 \%$ & $\operatorname{Max}$ & Mean \\
\hline Fibrinogen $(\mathrm{g} / \mathrm{l})$ & 7205 & 2.33 & 1.8 & 3.2 & 6.63 & 2.42 \\
\hline Black smoke $\left(\mu \mathrm{g} / \mathrm{m}^{3}\right)$ & 349 & 13 & 7.4 & 25.4 & 88.8 & 15.4 \\
\hline $\mathrm{PM}_{10}\left(\mu \mathrm{g} / \mathrm{m}^{3}\right)$ & 221 & 27.7 & 18.3 & 51.4 & 93.5 & 31.4 \\
\hline $\mathrm{SO}_{2}\left(\mu \mathrm{g} / \mathrm{m}^{3}\right)$ & 349 & 21 & 13.2 & 36.4 & 80.9 & 23.2 \\
\hline $\mathrm{CO}\left(\mathrm{mg} / \mathrm{m}^{3}\right)$ & 349 & 1.2 & 0.7 & 2.3 & 9.9 & 1.4 \\
\hline $\mathrm{NO}_{2}\left(\mu \mathrm{g} / \mathrm{m}^{3}\right)$ & 341 & 72.7 & 48.4 & 110.1 & 378.8 & 78.6 \\
\hline $\mathrm{O}_{3}\left(\mu \mathrm{g} / \mathrm{m}^{3}\right)$ & 299 & 29.5 & 8 & 54.9 & 101.3 & 31.4 \\
\hline Min temp $\left({ }^{\circ} \mathrm{C}\right)$ & 349 & 8 & 3 & 15 & 18 & 8.7 \\
\hline Humidity (\%) & 349 & 72 & 58 & 85 & 96 & 71.8 \\
\hline
\end{tabular}

Table 2 Pearson correlations between air pollutants, logarithm of fibrinogen, temperature, and humidity

\begin{tabular}{lllllllrr}
\hline & $\begin{array}{c}\text { Black } \\
\text { smoke }\end{array}$ & $\mathrm{PM}_{10}$ & $\mathrm{SO}_{2}$ & $\mathrm{CO}$ & $\mathrm{NO}_{2}$ & \multicolumn{1}{c}{$\mathrm{O}_{3}$} & $\begin{array}{l}\text { Tempe } \\
\text { rature }\end{array}$ & Humidity \\
\hline Fibrinogen & 0.03 & 0.02 & 0.02 & 0.04 & 0.03 & -0.04 & -0.00 & 0.01 \\
Black smoke & & 0.56 & 0.69 & 0.89 & 0.75 & -0.45 & -0.42 & 0.20 \\
$\mathrm{PM}_{10}$ & & & 0.70 & 0.57 & 0.76 & 0.10 & 0.01 & -0.12 \\
$\mathrm{SO}_{2}$ & & & & 0.61 & 0.62 & -0.12 & -0.34 & -0.06 \\
$\mathrm{CO}$ & & & & 0.81 & -0.45 & -0.34 & 0.22 \\
$\mathrm{NO}_{2}$ & & & & & -0.05 & -0.10 & -0.00 \\
$\mathrm{O}_{3}$ & & & & & & 0.29 & -0.45 \\
Temperature & & & & & & & & -0.18 \\
\hline
\end{tabular}

Table 3 Adjusted ${ }^{\star}$ associations between different lags of air pollutants and fibrinogen

\begin{tabular}{|c|c|c|c|c|c|c|}
\hline Pollutant & $n$ & $\begin{array}{l}\text { Difference } \\
(\%)\end{array}$ & $\begin{array}{l}S E \\
+(\%)\end{array}$ & $p$ Value & $\begin{array}{l}\text { Odds } \\
\text { ratio } \neq \neq\end{array}$ & $p$ Value \\
\hline \multicolumn{7}{|c|}{ Black smoke: } \\
\hline Lag 0 & 7205 & 0.92 & 0.52 & 0.08 & 1.14 & 0.11 \\
\hline Lag 1 & 7205 & 0.64 & 0.56 & 0.25 & 1.01 & 0.91 \\
\hline Lag 2 & 7205 & 0.25 & 0.60 & 0.68 & 1.02 & 0.80 \\
\hline Lag 3 & 7205 & 0.81 & 0.49 & 0.10 & 1.17 & 0.05 \\
\hline \multicolumn{7}{|l|}{$\mathrm{PM}_{10}:$} \\
\hline Lag 0 & 4165 & 0.24 & 0.83 & 0.77 & 1.00 & 0.99 \\
\hline Lag 1 & 4131 & 0.45 & 0.95 & 0.63 & 0.73 & 0.06 \\
\hline Lag 2 & 4042 & 0.51 & 0.97 & 0.60 & 0.93 & 0.66 \\
\hline Lag 3 & 4022 & 0.38 & 0.87 & 0.66 & 1.04 & 0.78 \\
\hline \multicolumn{7}{|l|}{$\mathrm{SO}_{2}:$} \\
\hline Lag 0 & 7205 & 0.83 & 0.61 & 0.18 & 1.17 & 0.11 \\
\hline Lag 1 & 7205 & 0.34 & 0.63 & 0.59 & 1.19 & 0.09 \\
\hline Lag 2 & 7205 & -0.10 & 0.71 & 0.89 & 1.12 & 0.34 \\
\hline Lag 3 & 7205 & -0.07 & 0.66 & 0.92 & 1.11 & 0.33 \\
\hline \multicolumn{7}{|l|}{ CO: } \\
\hline Lag 0 & 7205 & 1.43 & 0.51 & $<0.01$ & 1.17 & 0.05 \\
\hline Lag 1 & 7205 & 1.49 & 0.51 & $<0.01$ & 1.09 & 0.31 \\
\hline Lag 2 & 7205 & 1.59 & 0.51 & $<0.01$ & 1.14 & 0.11 \\
\hline Lag 3 & 7205 & 1.26 & 0.45 & $<0.01$ & 1.22 & $<0.01$ \\
\hline \multicolumn{7}{|l|}{$\mathrm{NO}_{2}:$} \\
\hline Lag 0 & 7040 & 1.24 & 0.48 & 0.01 & 1.14 & 0.10 \\
\hline Lag 1 & 6988 & 1.47 & 0.54 & $<0.01$ & 1.12 & 0.21 \\
\hline Lag 2 & 6985 & 1.36 & 0.56 & 0.02 & 1.11 & 0.26 \\
\hline Lag 3 & 7024 & 1.36 & 0.47 & $<0.01$ & 1.22 & 0.01 \\
\hline \multicolumn{7}{|l|}{$\mathrm{O}_{3}:$} \\
\hline Lag 0 & 5862 & 0.21 & 1.00 & 0.83 & 0.93 & 0.69 \\
\hline Lag 1 & 5840 & 0.41 & 0.85 & 0.63 & 1.01 & 0.96 \\
\hline Lag 2 & 5887 & -0.24 & 0.78 & 0.75 & 1.10 & 0.45 \\
\hline Lag 3 & 5932 & -1.34 & 0.78 & 0.08 & 0.80 & 0.11 \\
\hline
\end{tabular}

^Adjusted for age, sex, employment grade, ethnicity, smoking, alcohol, body mass index, month, minimum daily temperature and relative humidity.

†Differences (\%), SEs, and odds ratios for an increase in concentration of pollutants from 10 th to 90th percentile (for black smoke $18 \mu \mathrm{g} / \mathrm{m}^{3}, \mathrm{PM}_{10} 33.1 \mu \mathrm{g} / \mathrm{m}^{3}, \mathrm{SO}_{2} 23.2 \mu \mathrm{g} / \mathrm{m}^{3}, \mathrm{CO} 1.6 \mathrm{mg} / \mathrm{m}^{3}, \mathrm{NO}_{2}$ $61.7 \mu \mathrm{g} / \mathrm{m}^{3}$, and $\left.\mathrm{O}_{3} 46.9 \mu \mathrm{g} / \mathrm{m}^{3}\right)$.

¥Odds ratios for having fibrinogen above $3.19 \mathrm{~g} / 1$ (highest $10 \%$ ).

logistic regression models, those $10 \%$ of the subjects with the highest fibrinogen (above $3.19 \mathrm{~g} / \mathrm{l}$ ) concentrations were defined as having high concentrations and the rest low concentrations. This binary variable was then regressed on the air pollutants. All analyses were done with SAS. ${ }^{20}$

Pollution data on the day when blood sampling was done (lag 0 ) and on three previous days (lags 1-3) were matched for each individual subject. Pollutants were modelled as continuous variables. Initially, analyses were done for the four lags with the whole data set. Further analyses were done in subgroupsnon-smokers, men and women, and cool season (October to March) and warm season (April to September)..$^{10} 11$

All analyses were adjusted for 5 year age group, sex, employment grade (six categories), ${ }^{21}$ ethnicity (four categories: European, South Asian, Afro-Caribbean, other), smoking (three categories: never, ex, current), body mass index, alcohol consumption, month of examination (21 categories) to model seasonality in fibrinogen concentrations, minimum temperature, and relative humidity. Body mass index, alcohol, temperature, and humidity were entered as continuous variables, all other variables were treated as categorical. These adjustments made very little difference and only adjusted analyses are reported here. Further adjustments for the type of building, where the person worked, for maximum temperature, or for weekday, had little effect on the results.

All results are reported for an increase in the pollutant concentration from its 10th to its 90th percentile. Therefore, the odds ratios derived from logistic regression can be interpreted as the relative risk for having a high concentration of fibrinogen in a high pollution day (90th percentile) compared with a low pollution day (10th percentile). As fibrinogen was logarithmically transformed for the linear regression analyses, the analyses give the relative difference in fibrinogen for a given change in the pollutant. The results are reported as the mean (SEM) of \% difference in fibrinogen associated with increase in the pollutant concentration from 10 th to 90 th percentile, which were calculated by multiplying the original regression coefficient (SEM) by number of units of air pollution between the 10th and 90th percentiles, taking the exponent of this, then subtracting one, and multiplying by 100 .

\section{Results}

Haemostatic data were collected from September 1991 to May 1993. Except for $\mathrm{PM}_{10}$ and $\mathrm{O}_{3}$, and six missing days of $\mathrm{NO}_{2}$, air pollutant data were available for 349 days during which blood was collected (table 1). The analyses focus on the 7205 office workers examined on those days who had non-missing data on the confounders needed for the multivariate models.

Correlations between all pollutants, except $\mathrm{O}_{3}$, were high and positive (table 2). Lowest correlations, around 0.6 , were found for $\mathrm{PM}_{10}$ with black smoke and with CO. Highest correlations, around 0.8-0.9, were found for $\mathrm{CO}$ with $\mathrm{NO}_{2}$ and with black smoke. Ozone correlated negatively with all other pollutants, but especially with CO and black smoke $(-0.45)$.

In the linear regression analyses, fibrinogen concentrations were significantly and positively associated with all lags of $\mathrm{CO}$ and $\mathrm{NO}_{2}$, but not with other pollutants. The findings from the logistic regression analyses were generally in the same direction, but less significant (table 3 ).

The consistency of the associations found at lag 1 was then analysed in subgroups defined by season, sex, and smoking. The association of $\mathrm{NO}_{2}$ and ozone with fibrinogen tended to be stronger among women than men (table 4). 
Table 4 Adjusted ${ }^{\star}$ associations of previous day's concentration of the air pollutants (lag 1) with fibrinogen in subgroups defined by smoking, sex, and season

\begin{tabular}{|c|c|c|c|c|}
\hline Model & $n$ & $\begin{array}{l}\text { Differencet } \\
(\%)\end{array}$ & $\begin{array}{l}S E+ \\
(\%)\end{array}$ & $p$ Value \\
\hline \multicolumn{5}{|l|}{ Black smoke: } \\
\hline All & 7205 & 0.64 & 0.55 & 0.25 \\
\hline Non-smokers & 3690 & 1.55 & 0.76 & 0.04 \\
\hline Men & 4982 & 0.43 & 0.63 & 0.49 \\
\hline Women & 2223 & 0.78 & 1.28 & 0.54 \\
\hline Warm season & 3274 & 3.02 & 1.46 & 0.04 \\
\hline Cool season & 3931 & 0.56 & 0.63 & 0.38 \\
\hline \multicolumn{5}{|l|}{$\mathrm{PM}_{10}:$} \\
\hline All & 4131 & 0.45 & 0.94 & 0.63 \\
\hline Non-smokers & 2028 & -0.88 & 1.33 & 0.51 \\
\hline Men & 2955 & 0.35 & 1.07 & 0.74 \\
\hline Women & 1176 & -0.05 & 2.13 & 0.98 \\
\hline Warm season & 2129 & 3.24 & 1.29 & 0.01 \\
\hline Cool season & 2002 & -0.58 & 1.53 & 0.70 \\
\hline \multicolumn{5}{|l|}{$\mathrm{SO}_{2}$ : } \\
\hline All & 7205 & 0.34 & 0.63 & 0.59 \\
\hline Non-smokers & 3690 & 1.31 & 0.86 & 0.13 \\
\hline Men & 4982 & -0.18 & 0.70 & 0.80 \\
\hline Women & 2223 & 2.22 & 1.46 & 0.13 \\
\hline Warm season & 3274 & 0.64 & 1.24 & 0.60 \\
\hline Cool season & 3931 & 1.06 & 0.85 & 0.22 \\
\hline \multicolumn{5}{|l|}{ CO: } \\
\hline All & 7205 & 1.48 & 0.51 & $<0.01$ \\
\hline Non-smokers & 3690 & 1.95 & 0.70 & $<0.01$ \\
\hline Men & 4982 & 1.22 & 0.58 & 0.04 \\
\hline Women & 2223 & 1.91 & 1.29 & 0.14 \\
\hline Warm season & 3274 & 4.20 & 1.57 & $<0.01$ \\
\hline Cool season & 3931 & 1.56 & 0.56 & $<0.01$ \\
\hline \multicolumn{5}{|l|}{$\mathrm{NO}_{2}$ : } \\
\hline All & 6988 & 1.46 & 0.53 & $<0.01$ \\
\hline Non-smokers & 3584 & 1.45 & 0.74 & 0.05 \\
\hline Men & 4828 & 0.86 & 0.60 & 0.15 \\
\hline Women & 2160 & 3.27 & 1.33 & 0.01 \\
\hline Warm season & 3231 & 3.37 & 0.92 & $<0.001$ \\
\hline Cool season & 3757 & 1.25 & 0.76 & 0.10 \\
\hline \multicolumn{5}{|l|}{$\mathrm{O}_{3}$ : } \\
\hline All & 5840 & 0.41 & 0.84 & 0.63 \\
\hline Non-smokers & 3000 & -0.04 & 1.14 & 0.97 \\
\hline Men & 4100 & -0.76 & 1.03 & 0.45 \\
\hline Women & 1740 & 3.07 & 1.66 & 0.07 \\
\hline Warm season & 3015 & 0.51 & 1.11 & 0.65 \\
\hline Cool season & 2825 & 1.30 & 1.37 & 0.34 \\
\hline
\end{tabular}

^Adjusted for age, sex, employment grade, ethnicity, smoking, alcohol, body mass index, month, minimum daily temperature, and relative humidity.

† Differences (\%) and SEs are reported for an increase in concentration of pollutants from 10th to 90 th percentile (for black smoke $18 \mu \mathrm{g} / \mathrm{m}^{3}, \mathrm{PM}_{10} 33.1 \mu \mathrm{g} / \mathrm{m}^{3}, \mathrm{SO}_{2} 23.2 \mu \mathrm{g} / \mathrm{m}^{3}$, CO 1.6 $\mathrm{mg} / \mathrm{m}^{3}, \mathrm{NO}_{2} 61.7 \mu \mathrm{g} / \mathrm{m}^{3}$, and $\mathrm{O}_{3} 46.9 \mu \mathrm{g} / \mathrm{m}^{3}$ ).

Black smoke, $\mathrm{PM}_{10}, \mathrm{CO}$, and $\mathrm{NO}_{2}$ tended to be more strongly associated with fibrinogen in the warm season. The results among nonsmokers were in general similar to the results among all subjects.

These subgroup analyses were repeated for $\mathrm{CO}$ and $\mathrm{NO}_{2}$ at lag 3, as they showed a significant association also in the logistic regression models (table 3). The results from these subgroup analyses were similar to the results obtained for both $\mathrm{CO}$ and $\mathrm{NO}_{2}$ at lag 1 (table 4).

Logistic regression analyses were also done in subgroups defined by season, sex, and smoking (data not shown). In these analyses, the direction of the associations between air pollutants and fibrinogen were in general consistent with the linear regression analyses (table 4), but associations were less significant. There were, however, two exceptions. Firstly, the direction of the associations between $\mathrm{PM}_{10}$ and fibrinogen were not consistent between the linear and logistic regression analyses. Secondly, significant associations for $\mathrm{SO}_{2}$ were found in the logistic regression analyses only in the cool season and among non-smokers.
Multipollutant models were then run separately for the cool and warm season. During the warm season, the associations of black smoke, $\mathrm{PM}_{10}, \mathrm{NO}_{2}$, and $\mathrm{CO}$ at lag 1 all became non-significant with simultaneous adjustment. This was generally the case also in two pollutant models. The strength of the association of black smoke was little affected by adjustment for other pollutants. The coefficient for $\mathrm{PM}_{10}$ was reduced from $3.2 \%$ to $1.7 \%$, when adjusting for black smoke, but adjusting for other pollutants had little effect. The coefficients for $\mathrm{NO}_{2}$ and $\mathrm{CO}$ varied from model to model. During the cool season, both $\mathrm{NO}_{2}$ (lag 3) and CO (lag 3) lost their significance when adjusted for the effect of other pollutants.

Factor VIIc coagulant activity was also measured in the Whitehall II participants at the second screening examination by an automated clotting method with rabbit thromboplastin. ${ }^{22}$ Median concentration of factor VIIc was $87.3 \%$. Daily mean factor VIIc concentrations declined with time (correlation -0.22 with study day). Adjusting for the month of the study changed the direction of the associations of factor VIIc with black smoke, $\mathrm{CO}$, and $\mathrm{NO}_{2}$, so that in the adjusted analyses all lags of all pollutants were significantly negatively associated with factor VIIc concentrations. The strongest associations for each pollutant were lag 2 of black smoke ( $\%$ difference) $-3.4 \%$, $\mathrm{p}<0.001$, lag 3 of $\mathrm{PM}_{10}-3.4 \%, \mathrm{p}<0.001$, lag 2 of $\mathrm{SO}_{2}-3.3 \%$, p $<0.001$, lag 0 of $\mathrm{CO}-1.4 \%$, $\mathrm{p}=0.02$, lag 3 of $\mathrm{NO}_{2}-1.8 \%, \mathrm{p}<0.01$, and lag 1 of $\mathrm{O}_{3}-2.9 \%, \mathrm{p}<0.01$. None of the variables available were able to explain the inverse association.

\section{Discussion}

In the present study of office workers in London, daily concentrations of $\mathrm{NO}_{2}$ and $\mathrm{CO}$ were associated with increased plasma fibrinogen concentration in both seasons, with similar associations for black smoke and $\mathrm{PM}_{10}$ in the warm season. These results support the proposal ${ }^{14}$ that the association between air pollution and cardiovascular events may at least partly be mediated by haemostatic or inflammatory mechanisms.

Several studies have reported associations of daily variations in $\mathrm{CO}$, particulates, $\mathrm{O}_{3}, \mathrm{NO}_{2}$, and $\mathrm{SO}_{2}$ with daily changes in cardiovascular mortality and morbidity. ${ }^{1-11}$ The results seem to be most consistent for particulate air pollution and probably $\mathrm{CO}^{3}{ }^{23}$ Although the relative risks of cardiovascular mortality are usually smaller than respiratory mortality, the largest number of excess deaths due to particulate air pollution are attributable to cardiovascular diseases, as the absolute risk of cardiovascular disease in western societies is high. ${ }^{122425}$

It has been suggested ${ }^{14}$ that the many ultrafine particles in urban air may promote inflammation of lung epithelium, which would increase the concentrations of acute phase proteins-like fibrinogen-which in turn have been shown to be risk factors for cardiovascular diseases. ${ }^{16}$ Also $\mathrm{NO}_{2}, \mathrm{O}_{3}$, and $\mathrm{SO}_{2}$ are capable of producing inflammatory reactions in the lungs, ${ }^{23}$ and could thereby also increase fibrino- 
gen concentrations. Fibrinogen is a well known risk factor for myocardial infarction, thrombotic stroke, and claudication, but not other cardiovascular end points. ${ }^{16}$

An association between air pollution and increased plasma viscosity, for which fibrinogen is a major determinant, has earlier been reported in a cross sectional study. ${ }^{17}$ During the field work of that study, there occurred a major air pollution episode characterised by high concentrations of $\mathrm{SO}_{2}$ and particulates, but not CO. Subjects studied during the air pollution episode had higher plasma viscosity than other subjects. There was a strong decline in temperature during the episode, which makes the separation of the effects of air pollution and temperature difficult. However, in further analyses, $\mathrm{CO}$ was associated with increased plasma viscosity among women after adjusting for the air pollution episode. This association was found mainly with logistic regression analyses, where the end point analysed was the proportion of subjects with high plasma viscosity. ${ }^{17}$ Although we also found an association between $\mathrm{CO}$ and fibrinogen, the association was more consistent in the linear regression than in the logistic regression analyses.

Fibrinogen is one potential mechanism linking air pollution to cardiovascular disease, but other mechanisms probably also exist. This has been shown for CO, which by forming carboxyhaemoglobin decreases the exercise capacity in patients with coronary artery disease. ${ }^{26}{ }^{27}$ Several recent studies have shown an association between particulate air pollution and variability in heart rate, which in turn is associated with cardiovascular risk. ${ }^{28}$ The effect of air pollution may also be mediated through toxic effects on the respiratory system. There are several studies showing an association of particulates, $\mathrm{NO}_{2}, \mathrm{O}_{3}$, and $\mathrm{SO}_{2}$ with respiratory infections, ${ }^{23}$ which are associated with increased plasma fibrinogen, ${ }^{29}$ and which may also exacerbate pre-existing cardiovascular diseases. ${ }^{30}$

There is some coherence between our results and those of two time series studies of daily cardiovascular events in London over the same period, and with the same pollutant indicators (except that $\mathrm{PM}_{10}$ was not measured). A study of cardiovascular mortality ${ }^{10}$ found significant associations with $\mathrm{NO}_{2}$ and $\mathrm{SO}_{2}$, but not black smoke, in the warm season. A study of emergency admissions for acute myocardial infarction ${ }^{11}$ found associations with $\mathrm{NO}_{2}, \mathrm{SO}_{2}$, $\mathrm{CO}$, and black smoke, but for reasons we cannot reconcile with our study or the mortality study, these were found mainly in the cool season.

In the present analyses, a difference between the lowest and the highest decile of both $\mathrm{NO}_{2}$ and $\mathrm{CO}$ was associated with a $1.5 \%$ difference in fibrinogen. The same difference in $\mathrm{NO}_{2}$ and $\mathrm{CO}$ was associated with a $2.8 \%$ and a $3.6 \%$ increase in admissions to hospital for myocardial infarction, respectively, as estimated for the earlier analyses from London. ${ }^{11}$ As previous studies have suggested that a $1 \%$ increase in fibrinogen concentration is associated with a $1.7 \%$ increase in risk of myocardial infarction, ${ }^{31}$ the increase in fibrinogen found in the present study is in the correct order of magnitude to explain the association of $\mathrm{NO}_{2}$ and $\mathrm{CO}$ with myocardial infarction.

The present, and previous, ${ }^{11}$ analyses were not able to separate the effects of different pollutants due to their high correlations. Therefore, the pollutants used in the present analyses can mainly be regarded as indicators of the pollutant mix prevailing in any given day, as well as being measurements of the specific pollutants. Carbon dioxide and $\mathrm{NO}_{2}$, and to a lesser extent black smoke, are good indicators of traffic pollution. This may explain the association of $\mathrm{CO}$ with fibrinogen, as it is unlikely that $\mathrm{CO}$ by itself would induce inflammation and affect fibrinogen concentrations.

The proxy for personal exposure, as in previous time series studies, ${ }^{10}{ }^{11}$ was concentrations of air pollution in a few monitoring sites in London. If this error in the measurement of exposure is random, the true association between air pollution and fibrinogen may be stronger than reported here. In the present study, as in the earlier German study, ${ }^{17}$ subjects were studied only once. This also introduces a possibility of systematic bias. We conducted a search for possible indicators of such bias, such as place of work, but were unable to detect any.

We also found in passing that air pollution was inversely associated with factor VIIc concentrations. Factor VIIc was included in the present analyses mainly for exploratory purposes, as we are not aware of data suggesting that factor VIIc is an acute phase reactant. Factor VIIc is also a less well established risk factor for myocardial infarction than fibrinogen. However, if other studies confirm this relation, the reasons for such an association merit investigation.

In summary, the present results support the idea that at least part of the short term association between air pollution especially from traffic and cardiovascular mortality and morbidity is mediated through increased concentrations of fibrinogen, possibly due to an inflammatory reaction caused by air pollution.

The Whitehall II study has been supported by grants from the Medical Research Council, British Heart Foundation, Health and Safety Executive, National Heart Lung and Blood Institute (HL36310), National Institute of Ageing (AG13196), Agency for Health Care Policy Research (HS06516), The New England Medical Centre Division of Health Improvement, Institute for Work and Health, Toronto, and the John D and Catherine T MacArthur Foundation Research Networks on Successful Midlife Development and Socio-economic Status and Health. Midlife Development and Socio-economic Status and Health. We also thank all participating civil service departments and their welfare, personnel, and establishment officers; the Occupational Health and Safety Agency; the Council of Civil Service Unions; all participating civil servants in the Whitehall study; and all members of the Whitehall II study team. EJB was supported by the British Heart Foundation.

1 Katsouyanni K, Karakatsani A, Messari I, et al. Air pollution and cause specific mortality in Athens. F Epidemiol Community Health 1990;44:321-4.

2 Morris RD, Naumova EN, Munasinghe RI. Ambient air pollution and hospitalization for congestive heart failure among elderly people in seven large US cities. Am F Public Health 1995;85:1361-5.

3 Pope CA, Dockery DW, Schwartz J. Review of epidemiological evidence of health effects of particulate air pollution. Inhal Toxicol 1995;7:1-18.

4 Schwartz J, Morris R. Air pollution and hospital admissions for cardiovascular diseases in Detroit, Michigan. Am f Epidemiol 1995;142:23-35.

5 Burnett RT, Cakmak S, Brook JR, et al. The role of particulate size and chemistry in the association between summer- 
time ambient air pollution and hospitalization for cardiorespiratory diseases. Environ Health Perspect 1997;105: orespiratory 614 .

6 Wietlisbach V, Pope CA 3rd, Ackermann-Liebrich U. Air pollution and daily mortality in three Swiss urban areas. Soz Praventivmed 1996;41:107-15.

7 Zmirou D, Barumandzadeh T, Balducci F, et al. Short term effects of air pollution on mortality in the city on Lyon, France 1985-90. F Epidemiol Community Health 1996; 50(suppl 1):S30-5.

8 Schwartz J. Air pollution and hospital admissions for cardiovascular disease in Tucson. Epidemiology 1997;8: 371-7.9

9 Wordley J, Walters S, Ayres JG. Short term variations in hospital admissions and mortality and particulate air pollution. Occup Environ Med 1997;54:108-16.

10 Anderson HR, Ponce de Leon A, Bland JM, et al. Air pollution and daily mortality in London: 1987-92. BMY tion and daily

11 Poloniecki JD, Atkinson RW, Ponce de Leon A, et al. Daily time series for cardiovascular hospital admissions and previous day's air pollution in London, UK. Occup Environ vious day's air pollution
Med 1997;54:535-40

12 Dockery DW, Pope CA, Xu X, et al. An association between air pollution and mortality in six US cities. $N$ Engl $\mathcal{F} \mathrm{Med}$ 1993;329:1753-9

13 Pope CA 3rd, Thun MJ, Namboodiri MM, et al. Particulate air pollution as a predictor of mortality in a prospective study of US adults. Am $\mathcal{F}$ Respir Critic Care Med 1995;151: 669-74.

14 Seaton A, MacNee W, Donaldson K, et al. Particulate air pollution and acute health effects. Lancet 1995;345:176-8.

15 Danesh J, Collins R, Appleby P, et al. Association of fibrinogen, C-reactive protein, albumin or leukocyte count with ies. $\mathcal{F A M A}$ 1998;279:1477-82.

16 Pearson TA, LaCava J, Weil HFC. Epidemiology of thrombotic-haemostatic factors and their association with thrombotic-haemostatic factors and their association with $1674 \mathrm{~S}-82 \mathrm{~S}$.

17 Peters A, Doring A, Wichmann H-E, et al. Increased plasma viscosity during an air pollution episode: a link to mortality ? Lancet 1997;349:1582-7.
18 Marmot MG, Davey Smith G, Stansfeld S, et al. Health inequalities among British civil servants: the Whitehall II inequalities among British civil ser
study. Lancet 1991;337:1387-93.

19 Clauss A. Gerinnungsphysiologische Schnellmethode zur Bestimmung des Fibrinogens. Acta Haematol 1957;17:23746

20 SAS Institute. SAS/STAT software: changes and enhancements through release 6.11. Cary, NC: SAS Institute, 1996.

21 Brunner E, Davey Smith G, Marmot M, et al. Childhood social circumstances, psychosocial and behavioural factors as determinants of plasma fibrinogen. Lancet 1996;347: 1008-13.

22 Brozovic M, Stirling Y, Harricks C, et al. Factor VII in an industrial population. Br f Haematol 1974;28:381-91.

23 Bascom R, Bromberg PA, Costa DA, et al. Health effects of outdoor air pollution. Am f Respir Crit Care Med 1996;153: 3-50.

24 Schwartz J. What are people dying of on high pollution days? Environ Res 1994;64:26-35.

25 Nevalainen J, Pekkanen J. The effect of particulate air pollution on life expectancy. Sci Total Environ 1998;217:137-41.

26 Adams KF, Koch G, Chatterjee B, et al. Acute elevation of blood carboxyhemoglobin to $6 \%$ impairs exercise performance and aggravates symptoms in patients with ischemic heart disease. $\mathcal{F}$ Am Coll Cardiol 1988;12:900-9.

27 Allerd EN, Bleecker ER, Chaitman BR, et al. Short-term effects of carbon monoxide exposure on the exercise performance of subjects with coronary artery disease. $N$ Engl f Med 1989;321:1426-32.

28 Stone PH, Godleski JJ. First steps toward understanding the pathophysiologic link between air pollution and cardiac mortality. Am Heart f 1999;138:804-7.

29 Woodhouse PR, Khaw KT, Plummer M, et al. Seasonal variations of plasma fibrinogen and factor VII activity in the elderly: winter infections and death from cardiovascular disease. Lancet 1994;343:435-9.

30 Bates DV. Health indices of the adverse effects of air pollution: the question of coherence. Environ Res 1992;59: pollution:

31 Meade TW, Ruddock V, Stirling Y, et al. Fibrinolytic activity, clotting factors, and long-term incidence of ischaemic heart disease the Northwick Park Heart Study. Lancet 1993;342:1076-9.

\section{Vancouver style}

All manuscripts submitted to Occup Environ Med should conform to the uniform requirements for manuscripts submitted to biomedical journals (known as the Vancouver style.)

Occup Environ Med, together with many other international biomedical journals, has agreed to accept articles prepared in accordance with the Vancouver style. The style (described in full in the $\mathcal{F} A M A[1]$ ) is intended to standardise requirements for authors, and is the same as in this issue.

References should be numbered consecutively in the order in which they are first mentioned in the text by Arabic numerals on the line in square brackets on each occasion the reference is cited (Manson[1] confirmed other reports[2][3][4][5]). In future references to papers submitted to Occup Environ Med should include: the names of all authors if there are three or less or, if there are more, the first three followed by et al; the title of journal articles or book chapters; the titles of journals abbreviated according to the style of Index Medicus; and the first and final page numbers of the article or chapter. Titles not in Index Medicus should be given in full.

Examples of common forms of references are:

1 International Committee of Medical Journal Editors. Uniform requirements for manuscripts submitted to biomed journals. 尹AMA 1993;269:2282-6.

2 Soter NA, Wasserman SI, Austen KF Cold urticaria: release into the circulation of histmaine and eosinophil chemotactic factor of anaphylaxis during cold challenge. chemotactic factor of anaphylaxis

3 Weinstein L, Swartz MN. Pathogenic properties of invading micro-organisms. In: Sodeman WA Jr, Sodeman WA, eds. Pathologic physiology, mechanisms of disease. Philadelphia: W B Saunders, 1974:457-72. 